\title{
Tales of the Unexpected: The Selection of British Party Leaders since 1963
}

\begin{abstract}
Jeremy Corbyn's election as Leader of the Labour Party in 2015 stunned observers and practitioners of British politics alike. In this article, we first outline a theoretical framework that purports to explain why political parties operating in parliamentary systems choose the leaders they do. We then examine 32 leadership successions involving five major British parties since 1963, and note that many of these were unexpected, in that they were triggered by unforeseen circumstances, such as the sudden death or resignation of the incumbent. Examining each party in turn, we briefly explain why the winners won and identify at least eight cases (a quarter of our sample) where a candidate widely expected to prevail at the outset was ultimately defeated by a 'dark horse', 'second favourite' or even 'rank outsider'. Of these, Corbyn's election in 2015 was the most unexpected and, consistent with the findings of studies of party leadership conventions in other parliamentary systems, namely Canada and Spain, suggests that ideological and policy concerns are sometimes more important than considerations of party unity and electability, especially when a leadership contest is dominated by party activists.
\end{abstract}

Keywords: Political parties; party leaders; leadership selection; parliamentary systems; Members of Parliament (MPs); party members; Britain; Canada; Spain; leadership conventions. 


\section{Tales of the Unexpected: The Selection of British Party Leaders since 1963}

Jeremy Corbyn's election as Leader of the Labour Party in 2015 stunned observers and practitioners of British politics (Dorey and Denham, 2016; Quinn, 2016). As Stark (1996: 9798) explains, few party leadership candidacies in Britain are unexpected, and there are many factors which 'drastically reduce' the potential field.

Selection rules limit the possibilities to MPs; nomination thresholds make it mathematically impossible for more than a certain number of MPs to be nominated for any one contest. But probably more important than these rules are the unofficial criteria for being considered a potential leader. Candidates must be sound in mind and body, have Cabinet or Shadow Cabinet experience, command confidence among colleagues, and be able to communicate with the nation via the media. They must also appear capable of satisfying the party's strategic goals of remaining united, winning elections, and governing competently. All of this is necessary in order to be perceived as serious "candidate material".

As we explain below, Corbyn clearly met the first of these 'unofficial criteria', but arguably few others, if any, besides.

In this article, following Sjoblom (1968) and Stark (1996), we first outline a theoretical framework which purports to explain why political parties in parliamentary systems choose the leaders they do. We then examine 32 leadership successions involving five major British parties since 1963, and note that many of these contests were themselves unexpected, in that they were triggered by unforeseen circumstances, such as the sudden death or resignation of the incumbent. Examining each party in turn, we briefly explain why the winners won and identify at least eight cases (a quarter of our sample) where a candidate widely expected to prevail at the outset was ultimately defeated by a 'dark horse', 'second favourite' or even 'rank outsider'. Of these, Corbyn's election in 2015 was the most unexpected and, consistent with the findings of studies of party leadership conventions in other parliamentary systems, namely Canada and Spain, suggests that ideological and policy concerns are sometimes more important than considerations of party unity and electability, especially when a leadership contest is dominated by party activists. 


\section{Who Wins, and Why?}

In attempting to explain party leadership successions in Britain since 1963, and specifically 'why the winners won', we seek to extend and enhance the work of Stark (1996) and Quinn (2012), who have previously addressed this question for the period from 1963 to 1995 and 2010 respectively. We also seek to expand and advance the growing scholarly literature on party leadership selection in Anglophone and European parliamentary democracies, where the same question has hitherto received little systematic investigation, and others considerably more. Examples here include Kenig's study of 143 party leadership contests and successions in 11 parliamentary democracies between 1964 and 2007 which asks 'Do wider selectorates produce more competitive contests?' The answer, he concludes, is 'no': 'larger selectorates tend to attract more candidates, but also tend to produce less competitive contests' (Kenig, 2009: 246). A more recent study of party leadership selection in the five principal Anglophone democracies (Australia, Canada, Ireland, New Zealand and the United Kingdom) between 1965 and 2009 asks 'Who selects the party leader?' and discovers 'significant change in selection methods in recent years. While not universal, the trend is away from selection by a small group of party elites towards empowerment of a party's rank and file members' (Cross and Blais, 2012a: 145146).

In other words, rules matter, to the extent that enfranchising extra-parliamentary party members can result in the election of a leader who would not have been so chosen had the choice remained solely with its parliamentarians. The 2010 election of Ed Miliband as Labour Party leader, and that of Jeremy Corbyn as his 2015 successor, is clear testimony to this. Moreover, this strongly suggests that the criteria adopted by extra-parliamentary party members when choosing a new leader may well be rather different to those criteria (pace Sjoblom and Stark) which shape the choices of MPs.

More recently still, a volume edited by Pilet and Cross (2014) organizes each of its 13 chapters on specific countries into four discrete sections, respectively entitled 'Who is the party leader?', 'Rules organizing leadership selection', 'Dynamics of party leadership contests' and 'Demographics and tenure of party leaders'. In the first of these, Tim Bale and Paul Webb devote six pages to the 'dynamics' of party leadership contests in Britain from 1965 to 2010, but provide little or no explanation of why the winners won many of these contests, including the Conservative Party leadership contest of 1965, the Liberal Party contests of 1967 and 1976, the Social Democratic Party (SDP) contest of 1982, the Liberal Democrat contest of 1988, and 
the Labour Party contests of 1976 and 1992 (Bale and Webb, 2014: 18-25). As the subsequent chapters on Austria, Belgium, Germany, Hungary, Italy, Norway, Portugal, Romania and Spain confirm, party leadership contests in most other European countries are seldom 'dynamic' or competitive affairs. Indeed, in all nine of these countries, most party leadership selections between 1965 and 2012 were 'contested' by a single candidate, with no competitors at all (Allern and Karlsen, 2014; Barbera et al., 2014; Chiru and Gherghina, 2014; Detterbeck and Rohlfing, 2014; Ennser-Jedenastik and Muller, 2014; Ilonszki and Varnagy, 2014; Lisi and Freire, 2014; Pilet and Wauters, 2014; Sandri et al., 2014).

Conversely, Cross and Blais (2012b) examine the factors that influence the decisions made by party leadership selectorates in Anglophone democracies at some length, and in considerable detail. Where the choice is made by parliamentarians alone, they argue, a host of variables may influence their decision, including 'their personal relationships with the candidates and any regional and socio-demographic affinities they may share'. Voters' perceptions of the candidates' relative electability, competence to lead the party in the legislature and ability to unite the party and build a strong extra-parliamentary organization, they argue, 'have all been important considerations in some contests'. In addition to these factors, they argue, we must also consider the role of the 'ideological and policy positioning of the candidates'. These are 'not particularly important' in parliamentary contests, which are rarely characterized by profound policy disagreements. Ideology, they conclude, is often an important factor in such contests, but is typically 'far from definitive' (Cross and Blais, 2012b: 147, 149).

When and where policy disputes do occur in party leadership contests, whether or not the choice of party leader is restricted to parliamentarians alone, these often reflect underlying intra-party ideological divisions or disagreements, particularly when a party is choosing a leader following a General Election defeat. On such occasions, the leadership contest is likely to be, to a considerable extent, a de facto post-mortem on why the party had lost - particularly if it had been in government - with some leadership contenders (or their supporters) alleging that the incumbent leader had presided over policies which were insufficiently congruent with the party's basic principles - or ideology. This has often been a characteristic of Labour leadership contests following a General Election defeat, with the left attributing such losses to the incumbent leadership's 'betrayal' in failing to pursue sufficiently 'socialist' policies. 
However, the Conservative Party has also evinced similar ideology/policy disputes when (s)electing a new leader following electoral defeat. The most notable example was in 1975, when Margaret Thatcher was the surprising (to many commentators) choice of successor to Edward Heath. Although it has widely been claimed subsequently that Thatcher's main appeal was that she simply was not Heath (nor was she closely associated with him, unlike her main rivals in the contest), Bailey and Cowley argue that her election was partly attributable to a yearning among many Conservative MPs for a different political stance and approach. Although she was certainly not a Thatcherite at this stage, closer inspection of her rhetoric and speeches did evince a nascent change of direction, which many Conservatives hankered after: 'The full details of Thatcherism may not have been clear ... but that she stood for something was. Ideology was a determining factor in how MPs voted and a clear factor in how the election was discussed' (Bailey and Cowley, 2015; Cowley and Bailey, 2000). Subsequently, following the Conservative Party's crushing General Election defeats to New Labour in 1997 and 2001, the ensuing leadership contests became a proxy for intra-Party debates about whether it had been too 'Thatcherite', or not 'Thatcherite' enough. Most recently, in the 2016 Conservative leadership contest, when Theresa May was eventually 'crowned' as leader following the elimination or withdrawal of the other contenders, her principal opponent, Andrea Leadsom, had been supported by those Conservative MPs who hankered after a clear reversion to Thatcherism, following the professed social liberalism of David Cameron, who much of the Conservative right had distrusted, even despised, since his election to the leadership in 2005.

As Cross and Blais (2012b: 151-152) explain, extra-parliamentary party members and activists are now formally a part of the leadership selectorate in many parties and might be expected, for several reasons, to be influenced by different factors, and hence behave differently to their parliamentary counterparts.

For one thing, they are certainly less likely than parliamentarians to know the candidates and thus factors such as friendship, and career incentives, are likely to be less significant in their voting decision. Ideology may be a more salient factor in expanded selectorates as May's law [of curvilinear disparity] suggests that party activists (e.g. convention delegates) should be more ideologically extreme and more strongly motivated by policy concerns than are parliamentarians. Conversely, electability might be less of a factor among the activists as, for the most part, their jobs are not dependent on the electoral success of their party. While activists surely prefer 
their party to be in government, they may not be as willing as MPs to sacrifice ideological concerns for electability.

Cross and Blais note that there is little systematic evidence on the voting behaviour of party members and activists in leadership contests. Most of the evidence that does exist, they explain, relates to the Canadian case, where the selectorate has been expanded for nearly a century, and is 'mostly restricted to studies of delegates to leadership conventions', not electorates in the more recent 'One Member, One Vote' contests. We return to this point in our Conclusion, and note that, while unexpected party leaders are rare in parliamentary systems, 'dark horse' candidates have sometimes 'emerged' as winners not only in the British context, but also in other parliamentary systems. Based on the findings of studies of party leadership conventions in two such countries, Canada and Spain, we conclude that Corbyn's election as Labour leader in 2015 appears to support Cross and Blais's contention that ideological and policy concerns can sometimes be more important selection criteria than considerations of a party's internal unity and electability, especially where such contests are dominated by party activists (Cross and Blais, 2012b: 153).

\section{Key Selection Criteria in Parliamentary Systems}

In 1968, Gunnar Sjoblom (1968) identified three strategic goals for parties operating in parliamentary systems: to remain united, win elections and implement policies. Adopting this framework, Stark argues that unity is a party's first-order goal. 'Only when a party is functioning as a cohesive unit', he explains, 'can it devote its full attention and resources to the second-order goal of winning elections. Electoral victory gives a party the power to begin to fulfil the third-order goal of turning promises into policies' (Stark, 1996: 125).

Parties in parliamentary systems, Stark argues, must consider these strategic goals when selecting their leaders. When assessing the relative merits of leadership candidates, a party's highest priority is to choose someone who will preserve party unity. 'Acceptability to all major segments of the party is the first-order criterion. However, only in extraordinary circumstances does this unity goal become an explicit consideration'. It is only likely to prove decisive on those rare occasions when a leadership contest takes place when a party is 'dangerously divided'. Otherwise, leadership candidates are assessed principally on the basis of their perceived ability to lead their party to victory in a General Election. Hence, electoral appeal, or 'electability', is the second-order criterion. In most instances, Stark argues, these first and 
second-order priorities are the main criteria used to assess leadership candidates. Some consideration must also be given, however, to their perceived ability to serve in government. Hence, 'competence', or the capacity to lead a successful administration, is the 'third-order' criterion (Stark, 1996: 126).

Valuable though Stark's refinement of Sjoblom's model is, the criterion of 'acceptability' needs to be considered more carefully than has traditionally been the case. There are two reasons for critiquing the seemingly common-sense notion of 'acceptability'. The first concerns the subjectivity of such judgements, because it depends on who is assessing the 'acceptability' of a leadership candidate, and according to what criteria. A party's parliamentarians are highly likely to adopt a different definition of 'acceptability' when evaluating leadership candidates, in comparison to their extra-parliamentary members or affiliates. For the former, 'acceptability' will often be inextricably linked to the candidates' likelihood of achieving party unity, and of leading it to victory in the next General Election. By contrast, while a party's grass-roots supporters would ideally prefer to see their party in government, their interpretation of 'acceptability' will sometimes place a rather higher emphasis on ideological stance or purity of principles, even if these render the party less attractive to the wider electorate.

The second reason why the criterion of 'acceptability' warrants more careful consideration is that it is often relational; that is, a leadership candidate might be judged 'acceptable' not only in terms of their own personal characteristics or credibility, but also in comparison to the perceived 'unacceptability' of their opponents - as was the case, for example, with Alec Douglas-Home in the Conservative Party leadership 'contest' of 1963 (Macmillan, 1973: 514).

Also warranting more careful consideration is Stark's notion of electoral appeal or 'electability', as this criterion is also subject to differing interpretations, depending either on ideological stance in a party, or/and whether the judgement is being made by a party's parliamentarians or grass-roots members. In many cases, MPs will choose a leader who is not considered to be 'too ideological', because this would militate against both promoting party unity and maximising the party's popularity by appealing to the 'median' voter (who is presumed to be repelled by perceived dogmatism). Of course, this raises an epistemological issue, namely the manner in which MPs make their judgements or acquire knowledge about the electability of a leadership candidate vis-à-vis electoral or public opinion. Unless these MPs carefully peruse opinion polls conducted at the time of the leadership election, or perhaps 
undertake their own private polling (unlikely, due to the resource constrains in terms of time and money), judgements about the candidates' 'electability' are likely to remain intuitive and subjective, and perhaps shaped by a priori assumptions about who the median voter is, or where the hallowed centre-ground of British politics is located at any particular juncture.

However, some MPs, and more particularly some of a party's grass-roots members, will be convinced that their party's 'electability' would be increased by adopting a stronger or more explicitly ideological stance. Certainly, if their party has just been defeated in a General Election, there will be some MPs, and probably rather more extra-parliamentary members, who insist that the absence or dilution of its professed ideology was a major reason for its defeat, either because erstwhile supporters felt the party had betrayed them by abandoning its basic principles, or because its perceived lack of ideology caused confusion among many voters about what exactly the party stood for, and which policy objectives it would pursue in government.

In the case of the Labour Party, for example, the left has frequently attributed the Party's lack of electoral appeal to an absence or abandonment of 'socialist' ideology and policies or, at least, a failure by the erstwhile leadership to explain and promote these with sufficient commitment and conviction. Certainly, the Bennites in the early 1980s, and the Corbynites today, were and are adamant that Labour's defeats in the 1979 and 2015 General Elections respectively were due not to the Party being too 'left-wing', but because it was too timid and 'conservative', and had thus 'betrayed' its supporters. Similarly, since 1990, many Conservatives have attributed each and every failure to win a General Election to the leadership's refusal to adhere to 'Thatcherism' - a charge levelled against David Cameron by the Conservative right following the 2010 General Election campaign, in which he had supposedly 'muddied the message'.

Since 1963, there have been 32 leadership successions involving five major British parties: Labour, the Conservatives, the Liberal Party, the SDP and the Liberal Democrats (the latter party having been created in 1988 following a merger between the Liberal Party and the SDP). Of these, 11 involved the Labour Party, 11 the Conservatives and 10 the Liberal Party, SDP and Liberal Democrats combined. In the following three sections, we examine the leadership successions involving each of these parties and, applying the key selection criteria of 'acceptability', 'electability' and 'competence' described above, briefly explain 'why the 
winners won'. In the first, we consider those involving the three 'third' parties: the Liberal Party, the SDP and the Liberal Democrats.

\section{From Thorpe to Farron: The Liberal Party, the SDP and the Liberal Democrats}

Between 1967 and 2015, there were 10 Liberal, SDP and Liberal Democrat leadership successions, of which two involved the Liberal Party, three the SDP and five the Liberal Democrats (see Table 1). On every occasion, the party in question was seeking to fill a vacancy, and there were no formal challenges to the incumbent. In 1982 and 1988, two new parties, the SDP and the Liberal Democrats, were seeking to fill the post of Party Leader for the first time. On every other occasion, a leadership succession was precipitated by the incumbent's resignation, of which several, notably those of Jo Grimond in 1967, Jeremy Thorpe in 1976 and Charles Kennedy in 2006, were sudden and traumatic for the party concerned and, to most outside observers, entirely unexpected.

Table 1: Liberal Party, SDP and Liberal Democrat Leadership Successions 1967-2015

\begin{tabular}{|l|l|l|l|l|l|l|}
\hline Year & Party & Context & Selectorate & 'Favourite' & Winner & Key Criterion \\
\hline 1967 & Liberal & Vacancy & MPs & Thorpe & Thorpe & Electability \\
\hline 1976 & Liberal & Vacancy & Members & Steel & Steel & Electability \\
\hline 1982 & SDP & Vacancy & Members & Jenkins & Jenkins & Acceptability \\
\hline 1983 & SDP & Vacancy & Uncontested & N/A & Owen & N/A \\
\hline 1987 & SDP & Vacancy & Uncontested & N/A & Maclennan & N/A \\
\hline 1988 & Lib Dem & Vacancy & Members & Ashdown & Ashdown & Electability \\
\hline 1999 & Lib Dem & Vacancy & Members & Kennedy & Kennedy & Electability \\
\hline 2006 & Lib Dem & Vacancy & Members & Campbell & Campbell & Acceptability \\
\hline 2007 & Lib Dem & Vacancy & Members & Clegg & Clegg & Electability \\
\hline 2015 & Lib Dem & Vacancy & Members & Farron & Farron & Electability \\
\hline
\end{tabular}

In 1983 and 1987, the succession for the SDP leadership was uncontested. In 1967, Jeremy Thorpe was elected by Liberal MPs. On every other occasion, the leader was chosen via a ballot of party members. On the eight occasions when the leadership was contested, the key selection criteria ('acceptability', 'electability' and 'competence') were arguably the same irrespective of the composition of the electorate. However, with the possible exception of the 1982 SDP contest, Liberal, SDP and Liberal Democrat MPs and party members did not anticipate that their new leader would ever become Prime Minister. Consequently, the key selection criteria on most occasions were arguably 'acceptability' and 'electability' - namely, 'to choose someone who would not divide the party and who might also draw favourable attention to the party's efforts' (Stark, 1996: 127). 
The SDP's leadership contest of 1982 was different in this respect because, over the previous year of its brief existence, there had been reason to believe the Party might soon help to form a government. As Stark (1996: 129) explains,

Given Roy Jenkins' greater age and experience, he was universally regarded as better qualified than David Owen to serve competently as Prime Minister. On the other hand, Owen's relative novelty and youth led many to feel he would have more electoral appeal at the [next] General Election. But Jenkins was the clear choice in terms of unity.... The Liberals' undoubted preference for Jenkins meant he could best maintain the solidarity of the Alliance with the Liberals, as well as the unity of the SDP itself.

Like Jenkins, Sir Menzies Campbell was seen as the strongest 'unity' candidate of the three who contested the Liberal Democrat leadership election of 2006. Hence, it was principally on the basis of 'acceptability' that these two 'elder statesmen' were elected by their respective parties (Crewe and King, 1995: 159-161; Denham and Dorey, 2007: 43). As Jenkins' biographer has argued, Owen made a strong showing in the SDP contest of 1982, but a clear majority of party members ultimately judged that Jenkins' central role in the formation of the SDP and good relations with the Liberals still gave him the stronger claim. Indeed, some of Jenkins' supporters might also have been influenced by the fact that the Liberal leader, David Steel, made little secret that his good working partnership with Jenkins was critical to the functioning of the Alliance, which would be imperilled were Owen to become SDP leader. Moreover, Steel intimated that if an SDP-Liberal Government were formed, he would readily serve under Jenkins, but less so under Owen (Campbell, 2015: 607-608; Jenkins, 1991: 569). An in-depth poll by YouGov, conducted mid-way through the Liberal Democrat leadership contest of 2006, found that Campbell was regarded by almost half (48\%) of party members as the candidate most likely to unite the party, with his two opponents Chris Huhne and Simon Hughes trailing on $26 \%$ and $15 \%$ respectively (YouGov, 2006). On the basis of this and other findings from the survey, Quinn (2010: 106) concludes as follows.

Campbell won because the Liberal Democrats were in turmoil after Kennedy's departure [and] a safe pair of hands was needed at this critical juncture. The requirement for unity was thus real and that helped Campbell. Electoral considerations, although 
important, were more of a medium-term problem; if the contest had been decided on that basis, Campbell could have struggled to defeat Huhne.

The other six Liberal and Liberal Democrat leaders were chosen principally on the basis of 'electability'. In 1967, the Liberal Party's electorate consisted of just 12 MPs, of whom only six (including Thorpe himself) voted for Thorpe on the first ballot, whilst Eric Lubbock and Emlyn Hooson won three votes apiece, whereupon they withdrew so that Thorpe could formally be crowned Liberal leader (Thorpe, 1999: 132). Liberal MPs recognised that he was the Party's most effective campaigner. He was now, after Grimond, the longest-serving Liberal MP and 'seemed to be his natural successor as leader. A highly extrovert personality, an excellent and regular performer on television and radio, he was already one of the party's bestknown figures' (Wallace, 1983: 59). 'Politician with a zest for action' was The Guardian's verdict in a headline published the morning after his election (The Guardian, 19 January 1967).

In 1976, both candidates, David Steel and John Pardoe, were 'acceptable' to Liberal Party members. Of the two, they concluded that Steel had the greater electoral appeal. In 1988, Liberal Democrat members chose Paddy Ashdown over Alan Beith, principally for the same reason (Stark 1996,: 127-128, 130-131). As Ashdown's Press Officer during and after the leadership campaign, Harriet Smith (1999: 21) later recalled.

It was ultimately Ashdown's desire to take risks with the future that ensured his success. His approach was more acceptable to the ex-SDP element (which at that time made up less than one-third of party members) and to those ex-Liberals who feared that a traditional Liberal-style leader would restrict the new party's appeal to potential new members and voters.

In 1999, Charles Kennedy and Simon Hughes were both 'acceptable' to party members. While Hughes succeeded in capturing the votes of most of the party's activists, Kennedy's support came largely from 'armchair' members, among whom he was the best-known candidate, owing to his media profile (Hurst, 2006: 101). As most of those who voted fell into the latter category, Kennedy won, principally because of his perceived electoral appeal. In 2007, Nick Clegg and Chris Huhne were both 'acceptable' to party members. Again, Clegg won principally because, in their opinion, he was the more 'electable' of the two. According to a YouGov poll for Sky News, $53 \%$ of party members believed that, of the two, Clegg had the greater electoral appeal, 
whereas only 9\% felt this was so of Huhne (Quinn 2010: 107-108; YouGov, 2007). In 2015, Tim Farron defeated Norman Lamb, partly for 'ideological' reasons (unlike Lamb, he had strongly opposed unpopular policies, notably the trebling of university tuition fees, introduced by the Conservative-Liberal Democrat coalition government), but principally, given the defeat of all but eight of the party's 57 MPs in the 2015 General Election, on the basis of his superior electoral appeal (Francis and Denham 2015).

Of the eight 'third' party contests, the 'favourite' and 'front-runner' invariably went on to win. In 1967, Thorpe was seen as the likeliest candidate to replace Grimond and also had 'the overwhelming support both of English Liberals in the constituencies and of the Young Liberals, who bombarded the MPs and Party Headquarters with telegrams declaring Jeremy to be their choice' (Bloch, 2014: 244-245; Cole, 2011: 159; Ingham, 2015: 315; Wallace, 1983: 59). In 1976, following a three-week campaign, Steel won decisively, receiving almost two-thirds of the votes and securing a majority in every region, except Pardoe's 'home' territory of Devon and Cornwall (Punnett, 1992: 138). In 1988, the effect of the Liberal Democrat campaign, if any, was to increase Ashdown's margin of victory. Ashdown was described as the 'man to beat' from the moment Steel announced he would not be a candidate. During the campaign itself, Alan Beith's attempts to improve his chances 'tended only to backfire' and weaken his support (Stark, 1996: 120; The Times, 12 and 21 May 1988). In 1999, Kennedy 'started as the clear front-runner and ... bookies' favourite' and 'maintained a comfortable lead' throughout (Alderman and Carter, 2000: 319, 324). In 2006, despite Campbell's allegedly 'lacklustre' performance during the campaign, the 'favourite', 'front-runner' and acting Party Leader secured a comfortably victory (58\% to Huhne's 42\%) in the end (Denham and Dorey, 2007: 43).

The effect of the 1982 SDP and 2007 and 2015 Liberal Democrat campaigns was in the opposite direction to 1988. In the 1982 SDP contest, Jenkins (who, according to The Times, had established 'an irresistible claim to the leadership' and was referred to in the same newspaper as the Party's 'yet to be anointed leader' following his re-election to the House of Commons in March) led throughout (The Times, 26 and 27 March, 1982). Owen, however, succeeded in closing much of the gap between Jenkins and himself over the course of the campaign, as did Huhne between the 'favourite', Clegg, who was 'quickly identified as the front-runner by journalists (and bookmakers)' and attracted the support of at least 39 of the party's 63 MPs, and himself during the Liberal Democrat campaign of 2007 (Branigan, 2007). 
Quinn, 2010: 107; Stark, 1996: 120). Indeed, following the latter contest, it was reported that had some 1,300 ballots delayed in the Christmas post been counted, Huhne would have won (Merrick, 2008). The closeness of the result was 'partly down to Huhne's aggressive campaign and activist-friendly policies', but also 'the perceived lacklustre campaign that Clegg ran' (Quinn, 2012: 154). In 2015, Farron was the clear 'favourite' from the outset and, although Lamb succeeded in closing the gap to some extent during the campaign, the result, once again, was never in doubt.

In sum, all eight 'third' party contests were won by the candidate widely expected to do so at the outset. In 1967, the Liberal 'campaign' was brief and conducted entirely in private. As it turned out, Steel's role as Thorpe's unofficial campaign manager was 'critical' in seeing his preferred candidate, and that of the outgoing leader, Jo Grimond, safely home to victory (Bartram, 1981: 68-71; Beaumont, 1997). The subsequent campaigns were longer, more expensive to organize and more conspicuous, but frequently described as 'bland' (Francis, 2010). Most received limited coverage in the national news media (Alderman and Carter, 2000), partly because of this perceived 'blandness', but also because whoever was elected was unlikely ever to become Prime Minister. In most cases, 'third' party contests were won and lost principally on the basis of 'electability', albeit in conjunction with voters' perceptions of the other strengths and weaknesses of rival candidates. For example, in retirement David Steel recalled of the Liberal leadership contest of 1976 that there was 'not much on policy to separate' Pardoe and himself. His personal assistant endorsed this view, noting that the contest had been principally about 'style and strategy', with Steel campaigning on his 'solid record', 'shrewd toughness', 'calm pragmatism' and 'obvious' electoral appeal (Steel, 1989: 114). During the campaign itself, a poll carried out by Marplan found that 'amongst the general public 64 per cent preferred Steel, compared with only 23 per cent who wanted Pardoe. Among Liberal voters, the margin had been wider, 68 per cent to 20 per cent' (Bartram, 1981: 128). When the result was announced, it transpired that Steel had won 12,541 (64.1\%) 'national' votes compared to Pardoe's 7,032 (35.9\%), once the ballots cast by 69,726 individual Party members had been 'weighted' to reflect regional variations in the size and strength of local parties (Bartram, 1981: 128; Stark, 1996: 5, 73-74).

\section{From Home to May: The Conservative Party}

Between 1963 and 2016, there were 11 Conservative Party leadership successions (see Table 2). Of these, the Party was seeking to fill a vacancy on seven occasions, following the 
incumbent's resignation. The remainder were triggered by a formal challenge to the incumbent, of which one (to John Major in 1995) followed the incumbent's own prior decision to resign as Party Leader, thereby forcing his opponents within the parliamentary Party to 'put up or shut up' (Alderman, 1996; Heppell, 2008: 98-114). Major's resignation was sudden and unexpected, as were those of Harold Macmillan in 1963 (Denham and O'Hara, 2008: 16; Heppell, 2008: 16-18) and David Cameron in 2016. Decisions to challenge the incumbent in a formal contest for the Party leadership, notably those of Margaret Thatcher in 1975 and Sir Anthony Meyer in 1989, were similarly unexpected (Cowley and Bailey, 2000; Heppell, 2008: 59, 74-75; Norton, 1990; Wickham-Jones, 1997).

Table 2: Conservative Party Leadership Successions 1963-2016

\begin{tabular}{|l|l|l|l|l|l|}
\hline Year & Context & Selectorate & 'Favourite' & Winner & Key Criterion \\
\hline 1963 & Vacancy & 'Magic Circle' & $\begin{array}{l}\text { Butler, Maudling, } \\
\text { Hailsham }\end{array}$ & $\begin{array}{l}\text { Douglas- } \\
\text { Home }\end{array}$ & Acceptability \\
\hline 1965 & Vacancy & MPs & Maudling & Heath & Electability \\
\hline 1975 & Challenge & MPs & Heath & Thatcher & 'Not Heath' \\
\hline 1989 & Challenge & MPs & Thatcher & Thatcher & All \\
\hline 1990 & Challenge & MPs & Thatcher & Major & Acceptability \\
\hline 1995 & Challenge & MPs & Major & Major & All \\
\hline 1997 & Vacancy & MPs & Hague & Hague & Acceptability \\
\hline 2001 & Vacancy & MPs; Members & Portillo & Duncan Smith & Acceptability \\
\hline 2003 & Vacancy & Uncontested & N/A & Howard & N/A \\
\hline 2005 & Vacancy & MPs; Members & Davis & Cameron & Electability \\
\hline 2016 & Vacancy & $\begin{array}{l}\text { MPs; Members } \\
\text { (uncontested) }\end{array}$ & May & May & All \\
\hline
\end{tabular}

In 2003, the succession was uncontested. In 1963, following Macmillan's resignation, Sir Alec Douglas-Home was informally selected by the 'magic circle' (Gilmour and Garnett, 1997: 186203; Heppell, 2008: 18-31). Between 1965 and 1997, four new leaders were elected, and two incumbents re-elected, by MPs alone. In 2001 and 2005, following a series of eliminative ballots among MPs, a new leader was elected via a ballot of Party members. On all 10 occasions when the leadership was contested, the key selection criteria ('acceptability', 'electability' and 'competence') were the same, irrespective of the composition of the selectorate.

In 1989 and 1995, two Prime Ministers, Thatcher and Major, defeated their respective challengers (the backbench MP and 'stalking horse' candidate, Meyer, and erstwhile Secretary of State for Wales, John Redwood) with predictable ease and were re-elected on the basis of 
all three of the 'standard' criteria (Alderman, 1996; Norton, 1990; Stark 1996: 130, 169). Conversely, in 1965 and 2005, there was little to choose between the two leading contenders on the first criterion of 'acceptability', but Heath and Cameron were seen as superior to Reginald Maudling and David Davis respectively on the second, and won principally on the basis of 'electability' (Denham and Dorey, 2006: 41; Heppell and Hill, 2009; Kerr, 2007; Quinn 2010: 114; Stark 1996: 127, 132).

Of the other six cases listed in Table 2, the leadership contest of 1975 is arguably unique, in that the winner, Thatcher, was not seen as the strongest candidate on any of the three 'standard' criteria. Indeed, there was a widespread expectation that Heath would be re-elected, in spite of having lost - albeit very narrowly - two general elections in 1974. Certainly, Heath was advised, by the Conservatives' Chief Whip, that 'according to soundings by the whips, [he] would be re-elected as leader of the party', an outcome which was also suggested by a consultation exercise conducted by the Party's 1922 Committee, which surveyed the preferences of Conservative peers and the extra-parliamentary Party. Heath was further encouraged by a Harris Poll published in the Daily Express on 3rd February (the day before the ballot) that his continued leadership was supported by $70 \%$ of Conservative voters (Heath, 1998: 532-533).

Yet, when the result of the ballot was announced, it was evident to Heath, and everyone else, that: 'We had all got it so badly wrong. Mrs Thatcher, against all expectations, had won the first ballot with 130 votes to my 119', whereupon Heath immediately withdrew from the contest (Heath, 1998: 334). The shock of this result reverberated far and wide, with an official in the United States' White House observing that 'Heath was unexpectedly defeated as Opposition leader', although the same official deemed it 'doubtful that Mrs Thatcher will win on the second ballot. A more likely victor is [the] popular Willie Whitelaw' (Ford Library, 1975a). Whitelaw himself, as Party Chairman, was shocked at Heath's defeat, having not realized the scale of 'the strong feeling against Ted Heath' in the parliamentary Party (Whitelaw, 1989: 141).

Having defeated Heath on the first ballot, Thatcher's principal opponent on the second, William Whitelaw, was generally presumed to be the more 'acceptable', 'electable' and 'competent' of the two. Yet Thatcher again performed much better than expected, attracting 146 votes compared to Whitelaw's 79, whereupon the aforementioned White House official remarked 
that this victory was 'as surprising as Whitelaw's poor showing', and indicated a considerable 'degree of unity within the Conservative Party', although he added that in the longer-term, 'she will have to move an appreciable distance from her position on the right wing of her party' (Ford Library, 1975b).

Whether or not Thatcher won because she was viewed by Conservative MPs as a right-wing candidate who would imbue the Party with more ideological vigour in challenging Labour has been the subject of considerable academic debate. Some scholars have contended that there were 'clear ideological forces at work' and that the Party's MPs 'wanted a shift. They wanted new policies and they wanted a turn to the right' (Bailey and Cowley, 2015; Cowley and Bailey, 2000: 599; Wickham-Jones, 1997: 89). However, Thatcher's right-wing stance at this time should not be exaggerated, for she was not yet a Thatcherite - she became more radical over time, partly spurred by the experience of being in office (just as Tony Benn moved decisively to the left during the 1970s, having been a 'technocratic' Minister in the late 1960s). Whatever expectation of ideological change existed among some Conservative MPs in 1975, it is still widely believed that the 'one principal reason' for Thatcher's victory was that she was 'not Heath' (Stark, 1996: 127). Certainly, even some of those Conservative MPs who did not vote for her acknowledged that her support was drawn from all sections of the parliamentary Conservative Party, not just the right (Prior, 1996: 99).

The remaining five winners were chosen principally on the grounds of 'acceptability'. In 1963, Douglas-Home 'emerged' as the candidate arguably best-placed to maintain party unity - or as one of his defeated rivals expressed it, 'the product of the tendency of the Conservative Party to play safe instead of taking a calculated risk' (Hailsham, 1975: 224). Douglas-Home himself recalled that he had not intended to seek the leadership, but was exhorted to do so by several senior Conservative parliamentarians who 'insisted that I could command the support of a solid majority in the Commons' (Home, 1976: 183).

In 1990, following Thatcher's resignation after the first ballot, Major was seen by the Party's MPs as superior in this respect to the instinctively pro-European Michael Heseltine. The importance of Europe in this contest is particularly instructive, as the problems Major subsequently encountered as leader were caused by the same issue (Cowley and Garry, 1998). According to one study, ideology was the single most important factor in the voting behaviour of MPs on the second ballot. The majority of 'pure Thatcherites' voted for Major, while most 
'critics of Thatcherism' supported Heseltine or Douglas Hurd. The ultimate reason for Major's success, however, was that he won most support among the 'Party faithful', who constituted the majority of Conservative MPs (Cowley, 1999). For similar reasons, William Hague was preferred by the Party's MPs to the instinctively pro-European Kenneth Clarke in 1997 (Heppell and Hill, 2008), and Iain Duncan Smith preferred to the same opponent by its wider membership in 2001 (Alderman, 1998; Alderman and Carter, 1991; Alderman and Carter, 2002; Heppell and Hill, 2010; Stark, 1996: 127, 130, 132). In 2016, Theresa May was seen by most of the Party's MPs as the candidate most likely to restore party unity following the British electorate's decision in a referendum to leave the European Union, and Cameron's subsequent resignation. According to the opinion polls, May was also seen by the general public (43\%) and Conservative voters (59\%) alike as the candidate best-equipped to serve as Prime Minister (Dunford and Kirk, 2016). As a long-serving Home Secretary, she was also seen as the candidate most 'competent' to serve as Prime Minister, and so lead a successful administration.

Of the ten Conservative contests since 1963, only four have been won by the 'front-runner'. In 1989, Thatcher was the clear favourite at the outset and maintained a large lead throughout, as did Major in 1995 (Alderman, 1996; Norton, 1990; Stark, 1996: 117-8, 168-9). In 1997, Hague was 'widely tipped as the eventual winner' at the close of nominations (Alderman, 1998: 10), as was May in 2016. On the other six occasions, the campaign profoundly affected, and ultimately changed, the outcome. In 1963, three candidates (R.A. Butler, Lord Hailsham and Maudling) conducted themselves in a manner that proved to be self-defeating, while DouglasHome prevailed by 'simply letting his name go forward and doing nothing to alienate any section of the Party' (Stark, 1996: 106-7). In 1965, 1975 and 1990, the 'favourites' were Maudling, Heath and Thatcher respectively, but all were guilty of complacency and their principal opponents on the first ballot (Heath, Thatcher and Heseltine) conducted far more active and well-organized campaigns (Stark, 1996: 107-111). On each occasion, the campaign resulted in victory for a 'dark horse' candidate who was not initially thought to be in the running (Douglas-Home) or did not contest the first ballot of MPs (Major), the 'second favourite' (Heath in 1965) (Baston, 2004: 254-255, 260; Daily Express, 27 July 1965: 1-2) or an 'outsider' (Thatcher in 1975).

In 2001 and 2005, the 'front-runners' were Portillo and Davis respectively, but like Butler and Hailsham (1963), Maudling (1963 and 1965), Heath (1975) and Thatcher (1990) each conducted himself in a manner that proved to be self-defeating, and ran an inferior campaign 
to that of his principal opponent(s) (Clarke and Duncan Smith in 2001, Cameron in 2005). As a result, both lost 'momentum' and were either eliminated (Portillo) or 'went backwards' (Davis) during the first 'phase' of the contest, which consisted of an initial 'screening' of candidates via a series of eliminative ballots among MPs. In both cases, expanding the leadership selectorate to give Party members the final decision between the top two candidates selected by MPs had resulted in longer, more expensive and more conspicuous campaigns. This, in turn, resulted in Portillo and Davis making costly mistakes and gave two 'outsiders', Duncan Smith and Cameron, the chance to become more widely-known within the Party, build 'momentum' and ultimately win against the odds (Alderman and Carter, 2002; Denham and Dorey, 2006; Heppell, 2008: 136-153, 174-193).

In sum, of the ten Conservative leadership contests since 1963, six have been won by a candidate who was not expected to do so at the outset. Of the six unexpected winners, however, most were seen by the Party's MPs as 'serious candidate material', in that they appeared to meet at least some of the 'unofficial' criteria for being considered a potential leader. In 1963, Douglas-Home was a popular and respected figure in the Party, with eight years of Cabinet or Shadow Cabinet experience, and had previously served as Leader of the House of Lords and Foreign Secretary. In 1965, Heath had served as Chief Whip for four years, and had six years of Cabinet or Shadow Cabinet experience, including the posts of Lord Privy Seal, President of the Board of Trade and Shadow Chancellor. In 1975, Thatcher had seven years of Shadow Cabinet and Cabinet experience, having served as Shadow Minister for Fuel and Power, Transport, Education and Science and Environment and as Secretary of State for Education and Science. At the time of the 1975 leadership election, she was shadowing the Treasury, a post in which she greatly impressed many MPs with her mastery of detail and skill in attacking her political opponents, and specifically Labour's Chancellor Denis Healey. In 1990, Major had three years of Cabinet experience, having served as Chief Secretary to the Treasury, Foreign Secretary and Chancellor of the Exchequer.

In 2001, Duncan Smith had four years of Shadow Cabinet experience, having served as Shadow Secretary of State for Social Secretary, and later for Defence. Many of the Party's MPs, however, recalled his perceived disloyalty to the previous Conservative government, and few considered him 'leadership material'. As a result, only 39 of them voted for him on the first ballot, 42 on the second and 54 on the third. In 2005, Cameron had only seven months of Shadow Cabinet experience prior to his election as Party Leader, but was seen by most of the 
Party's MPs as the candidate best able to communicate with the nation via the media (and hence the most 'electable' as Prime Minister). Taking this 'unofficial' criterion into account, 90 of them voted for Cameron on the second ballot, almost as many as did so for Davis (57) and Liam Fox (51) combined.

\section{From Wilson to Corbyn: The Labour Party}

Since 1963, there have been 11 Labour Party leadership successions (see Table 3). Of these, the Party was seeking to fill a vacancy on nine occasions, and two were precipitated by a formal challenge to the incumbent. Of the nine contests for the vacant position of Party Leader, two were triggered by the sudden and unexpected death of the incumbent (Hugh Gaitskell in 1963, John Smith in 1994). Of the other nine leadership successions, some (including the resignation of Harold Wilson as Prime Minister in 1976 and the formal challenge to Neil Kinnock by Tony Benn in 1988) were also sudden and, to most outside observers at least, almost entirely unexpected.

Table 3: Labour Party Leadership Successions 1963-2016

\begin{tabular}{|l|l|l|l|l|l|}
\hline Year & Context & Selectorate & 'Favourite' & Winner & Key Criterion \\
\hline 1963 & Vacancy & MPs & Wilson & Wilson & All \\
\hline 1976 & Vacancy & MPs & Callaghan & Callaghan & All \\
\hline 1980 & Vacancy & MPs & Foot & Foot & Acceptability \\
\hline 1983 & Vacancy & Electoral College & Kinnock & Kinnock & Acceptability \\
\hline 1988 & Challenge & Electoral College & Kinnock & Kinnock & All \\
\hline 1992 & Vacancy & Electoral College & Smith & Smith & All \\
\hline 1994 & Vacancy & Electoral College & Blair & Blair & All \\
\hline 2007 & Vacancy & Uncontested & N/A & Brown & N/A \\
\hline 2010 & Vacancy & Electoral College & David Miliband & Ed Miliband & Acceptability \\
\hline 2015 & Vacancy & Members/supporters & Burnham & Corbyn & Acceptability \\
\hline 2016 & Challenge & Members/supporters & Corbyn & Corbyn & Acceptability \\
\hline
\end{tabular}

When Blair stood down in 2007, the succession by Gordon Brown was uncontested. In 1963, 1976 and 1980, three new leaders were elected by the Party's MPs. Between 1983 and 2010, four new leaders were elected and one incumbent re-elected via an Electoral College, consisting of three party sections: the Parliamentary Labour Party (PLP), members of Constituency Labour Parties (CLPs) and affiliated organizations, principally trade unions. In 2015 and 2016, a new leader was first elected, and then re-elected, via a new 'One Member, One Vote' system, discussed below. On all 10 occasions when the leadership was contested, 
the key selection criteria 'acceptability', 'electability' and 'competence' were the same, irrespective of the composition of the electorate.

Harold Wilson was seen as superior to George Brown and James Callaghan on all three criteria in 1963 - Callaghan himself subsequently conceded that 'Harold Wilson had the stability and unifying influence that the Party needed' at that time (Callaghan, 1988: 150) - as was Callaghan to the five other candidates (Benn, Tony Crosland, Michael Foot, Denis Healey and Roy Jenkins) who stood in 1976. The 1980 contest was decided principally on the basis of 'acceptability'. Considerations of party unity were paramount, and Foot was considered the best candidate around whom the Party could unite, despite Healey's superior claims to both 'electability' and 'competence'. The 1983 contest was, again, decided principally on the basis of 'acceptability'. On this occasion, Neil Kinnock's 'soft-left' background and refusal to serve in the Wilson and Callaghan governments made him far more 'acceptable' to the Party as a whole than his nearest rival, Roy Hattersley. In 1988, Kinnock defeated Benn's challenge with predictable ease, and was re-elected on the basis of all three criteria. In 1992, John Smith was seen as far superior to Bryan Gould on all three criteria, as was Tony Blair to Margaret Beckett and John Prescott in 1994 (Stark, 1996: 127-131). With the possible exception of Wilson in 1963 (Heppell, 2010a; Heppell, 2010b: 30-41) the 'expected' winner of all seven of these contests at the close of nominations (Healey had been the clear 'favourite' in 1980, but subsequently lost that status following Foot's belated decision to enter the race) invariably went on to win (Alderman and Carter, 1993, 1995; Drucker, 1976, 1981, 1984; Heppell 2010b; Heppell and Crines, 2011; Heppell et al., 2010; Stark, 1996: 118-120).

However, the 'trend' established by the previous seven contests was halted in 2010, and then, in 2015, dramatically reversed. In 2010, there were five candidates, but the contest was effectively a two-horse race between the 'favourite', David Miliband, and his younger brother, Ed. Of the two, David Miliband was the more experienced, but both were seen by their parliamentary colleagues as 'serious candidate material'. Of the first preferences indicated on their ballot papers, David Miliband received 111 votes, while Ed secured 84. After four months of campaigning, Ed Miliband prevailed by the narrowest of margins. David Miliband had remained throughout the first choice of more Labour MPs and Party members than any other candidate, but Ed's far superior support in the affiliates' section of the Electoral College and the larger number of second preference votes he received in both the PLP and CLP sections 
proved decisive. According to the opinion polls, David Miliband was seen as the strongest candidate in terms of both 'electability' and 'competence', but he was clearly 'unacceptable' on ideological grounds to the leaders of the three largest trade unions affiliated to the Party (the GMB, UNISON and UNITE). Of the two, Ed was more 'acceptable' to the Electoral College as a whole (Dorey and Denham, 2011; Jobson and Wickham-Jones, 2011; Pemberton and Wickham-Jones, 2013; Quinn, 2012: 64-82).

Ideology again prevailed over electoral and pragmatic considerations in 2015 (Dorey and Denham, 2016; Quinn, 2016), albeit even more so than it had in 2010. The 'front-runner' was Andy Burnham and, based on the number of nominations received from Labour MPs, either Burnham (with 68) or Yvette Cooper (59) would have won had the choice of Party Leader been theirs alone. In 2014, however, a major change had been introduced to the Party's leadership election process, which was to have an instant, and dramatic, effect on the outcome. In order to reduce the influence of trade union leaders and officials in future leadership contests, the Electoral College had been replaced by a new system, in which there would be three categories of voters: full Party members, 'affiliated supporters' (mostly trade union members) and 'registered supporters', who could register to vote in any future leadership contest, having declared their support for Labour's 'aim and values' and paid a modest fee of three pounds. Henceforth, the Party Leader would be elected not by the PLP, or an Electoral College, but on the basis of 'One Member One Vote'.

In practice, the new system led to a dramatic surge in the number of both 'affiliate supporters' and 'registered supporters', most of whom voted for the veteran left-wing backbench MP, Jeremy Corbyn. Whereas Corbyn received just under $50 \%$ of the votes of full Party members, he was the first choice of $57.6 \%$ of 'affiliate supporters' and no fewer than $83.7 \%$ of 'registered supporters'. Apart from the sheer scale of Corbyn's victory, the most notable feature of the contest was that most of those who voted for him were strongly motivated by ideological considerations. Only $5 \%$ of his supporters believed he would maintain party unity, and only $5 \%$ believed he would lead Labour to victory in the next General Election. As these figures suggest, Corbyn was seen as by far the weakest candidate on all three of the 'standard' criteria: 'acceptability', 'electability' and, as the only one with no Cabinet or Shadow Cabinet experience, 'competence' (Dorey and Denham, 2016; Quinn, 2016). In 2016, following a vote of no confidence by the Party's MPs, Corbyn was formally challenged by Owen Smith. Unlike the previous contest, Corbyn was expected to win, and did so, achieving an increased majority 
(62\% to Smith's 38\%), and for essentially the same (principally ideological) reasons that he had secured the leadership almost exactly a year before.

\section{Conclusion}

In this article, we first outlined a theoretical framework which purports to explain why political parties in parliamentary systems choose the leaders they do. We then examined the 32 leadership successions involving five major British parties since 1963, in order to explain "why the winners won'. While most winning candidates were expected to prevail at the outset, we have identified several cases from Douglas-Home in 1963 to Corbyn in 2015 where the expected winner was ultimately defeated by a 'dark horse' candidate, 'second favourite' or even 'rank outsider'.

The decision by major British parties to expand their leadership selectorates beyond the parliamentary caucus has resulted in longer and more conspicuous campaigns. On four occasions since 2001, this has given a candidate not expected to win at the outset of a leadership campaign (Duncan Smith in 2001, Cameron in 2005, Ed Miliband in 2010, Corbyn in 2015) the time and opportunity to build 'momentum' and upset the odds. On four previous occasions between 1963 and 1990, an 'unexpected' winner was informally selected by a 'magic circle' of party notables (Douglas-Home in 1963) or formally elected by MPs alone (Heath in 1965, Thatcher in 1975 and Major in 1990). Of these eight examples, Corbyn's election as Labour leader in 2015 was the most 'unexpected'. Previous 'unexpected' winners were seen by their parliamentary colleagues as 'serious candidate material', in that they appeared to meet at least some of the 'unofficial' criteria for being considered a potential leader.

As we noted in our Introduction, unexpected party leaders are rare in parliamentary democracies. However, 'dark horse' candidates have sometimes 'emerged' as winners of formal, competitive contests not only in Britain, but also in other Anglophone and European democracies. As Cross (2014: 184-185) explains,

Leadership elections in Canada are typically competitive events ... Many leaders have won on the fourth or fifth ballot including Liberals Trudeau and Dion, Conservatives Stanfield, Clark and Mulroney, and New Democrats Broadbent, McLaughlin and Mulcair ... dark-horse candidates who trail on first ballots are occasionally able to receive majority support and win several ballots later. Stephane Dion and Joe Clark are 
both examples of candidates finishing third on the first ballot who ultimately won on a fourth ballot.

In the case of Spain, Barbera et al. (2014) note that Zapatero (Spanish Socialist Workers Party) in 2000, Hernandez-Mancha (People's Alliance) in 1987, Llamazares (United Left) in 2000 and Imaz (Basque National Party) in 2004 were not seen as front-runners at the outset of their respective contests, yet all were elected. In all four cases, they argue, these candidates 'challenged the party establishment' and 'sought to replace the incumbent generation' (Barbera et al., 2014: 120). In the British context, it can be argued that, for their part, Corbyn and his supporters similarly 'challenged the Party establishment' and sought to 'replace the incumbent generation' of apparatchiks and 'career' politicians in contesting the Labour leadership election of 2015 .

As Cross and Blais (2012b:152) note, Johnston's (1988) study of leadership conventions in the Canadian Conservative and Liberal parties in 1983 and 1984 asks whether ideology and policy were important factors in delegates' voting decision. It finds that 'The decisive factors in both Liberal and Conservative delegates' behaviour seemed to be ideas about policy' and that 'Most important in each party was left-right self-designation' (Johnston 1988: 215). Cross and Blais (2012b:153) conclude that the limited evidence we have on the role of ideology in parliamentary and extra-parliamentary leadership contests suggests that 'Policy concerns may be most important in contests dominated by party activists ... while more casual partisans, who participate in membership votes, and MPs, voting in the party room, may be equally or more concerned with questions of party unity and electability'. While most major British party leaders since 1963 have been selected by MPs and party members on the basis of their perceived 'acceptability', 'electability' and 'competence', Corbyn's election in 2015 and subsequent re-election in 2016 also suggests that ideological and policy concerns can sometimes be more important than considerations of a party's internal unity and electability, especially in contests 'dominated by party activists'. 


\section{References}

Alderman, K. (1996) The Conservative Party leadership election of 1995. Parliamentary Affairs 49(2): 316-332.

Alderman, K. (1998) The Conservative Party leadership election of 1997. Parliamentary Affairs 51(1): 1-16.

Alderman, K. and Carter, N. (1991) A very Tory coup: The ousting of Mrs Thatcher', Parliamentary Affairs 44(2): 125-139.

Alderman, K. and Carter, N. (1993) The Labour Party leadership and deputy leadership elections of 1992. Parliamentary Affairs 46(1): 49-65.

Alderman, K. and Carter, N. (1995) The Labour Party leadership and deputy leadership elections of 1994. Parliamentary Affairs 48(3): 438-455.

Alderman, K. and Carter, N. (2000) The Liberal Democrat leadership election of 1999. Parliamentary Affairs 53(2): 311-327.

Alderman, K. and Carter, N. (2002) The Conservative Party leadership election of 2001. Parliamentary Affairs 55(3): 569-585.

Allern, E.H. and Karlsen, R. (2014) Unanimous, by acclamation? Party leadership selection in Norway'. In: J.-B. Pilet and W.P. Cross (eds.) The Selection of Political Party Leaders in Contemporary Parliamentary Democracies: A Comparative Study. Abingdon: Routledge, 4761.

Bailey, M. and Cowley, P. (2015) The conventional wisdom is wrong. As Tory leader, Thatcher stood for ideology - right from the start, Conservativehome 23 March, available at http://www.conservativehome.com/platform/2015/03/matthew-bailey-and-philip-cowley-theconventional-wisdom-is-wrong-as-tory-leader-thatcher-stood-for-ideology-right-from-the$\underline{\text { start.html }}$ 
Bale, T, and Webb, P. (2014) The selection of party leaders in the UK. In: J.-B. Pilet and W.P. Cross (eds.) The Selection of Political Party Leaders in Contemporary Parliamentary Democracies: A Comparative Study. Abingdon: Routledge, 12-29.

Barbera, O., Rodriguez-Teruel, J., Barrio, A. and Baras, M. (2014) The selection of party leaders in Spain. In: J.-B. Pilet and W.P. Cross (eds.) The Selection of Political Party Leaders in Contemporary Parliamentary Democracies: A Comparative Study. Abingdon: Routledge, 108-123.

Bartram, P. (1981) David Steel: His Life and Politics. London: W.H. Allen.

Baston, L. (2004) Reggie: The Life of Reginald Maudling. Stroud: Sutton Publishing.

Beaumont, T. (1997) The election of Jeremy Thorpe to the Liberal leadership. Liberal Democrat History Group Newsletter 15, 5-6.

Bloch, M. (2014) Jeremy Thorpe. London: Little, Brown.

Branigan, T. (2007) 'All still to play for in Liberal Democrats' leadership race. The Guardian, 23 November.

Callaghan, J. (1988) Time and Chance. London: Fontana.

Campbell, J. (2015) Roy Jenkins. In: D. Brack, R.Ingham and T. Little (eds.) British Liberal Leaders: Leaders of the Liberal Party, SDP and Liberal Democrats since 1828. London: Biteback Publishing, 335-349.

Chiru, M. and Gherghina, S. (2014) Let's not risk too much: The selection of party leaders in Romania. In: J.-B. Pilet and W.P. Cross (eds.) The Selection of Political Party Leaders in Contemporary Parliamentary Democracies: A Comparative Study. Abingdon: Routledge, 141155.

Cole, M. (2011) Richard Wainwright, the Liberals and the Liberal Democrats: Unfinished Business. Manchester and New York: Manchester University Press. 
Cowley, P. (1999) How did he do that? The second round of the 1990 Conservative leadership contest. In: D.M. Farrell, D. Broughton, D. Denver and J. Fisher (eds.) British Elections and Parties Yearbook 1996. London: Frank Cass, 198-216.

Cowley, P. and Bailey, M. (2000) Peasants' uprising or religious war? Re-examining the 1975 Conservative leadership contest. British Journal of Political Science 30: 599-629.

Cowley, P. and Garry, J. (1998) The British Conservative Party and Europe: The choosing of John Major. British Journal of Political Science 28(3): 473-499.

Crewe, I. and King, A. (1995) SDP: The Birth, Life and Death of the Social Democratic Party. Oxford: Oxford University Press.

Cross, W.P. (2014) Party Leadership in Canada. In: J.-B. Pilet and W.P. Cross (eds.) The Selection of Political Party Leaders in Contemporary Parliamentary Democracies: A Comparative Study. Abingdon: Routledge, 171-188.

Cross, W.P. and Blais, A. (2012a) Who selects the party leader? Party Politics 18(2): 127-150. Cross, W.P. and Blais, A. (2012b) Politics at the Centre: The Selection and Removal of Party Leaders in the Anglo Parliamentary Democracies. Oxford: Oxford University Press.

Denham, A. and Dorey, P. (2006) A tale of two speeches? The Conservative leadership election of 2005. Political Quarterly 77(1): 35-42.

Denham, A. and Dorey, P. (2007) The 'caretaker' cleans up: The Liberal Democrat leadership election of 2006. Parliamentary Affairs 60(1): 26-45.

Denham, A. and O'Hara, K. (2008) Democratising Conservative Leadership Selection: From Grey Suits. Manchester and New York: Manchester University Press.

Detterbeck, K. and Rohlfing, I. (2014) Party leader selection in Germany'. In: J.-B. Pilet and W.P. Cross (eds.) The Selection of Political Party Leaders in Contemporary Parliamentary Democracies: A Comparative Study. Abingdon: Routledge, 77-92. 
Dommett, K. (2015) The theory and practice of party modernisation: The conservative party under David Cameron, 2005-2015, British Politics 10(2) 249-266.

Dorey, P. and Denham, A. (2011) 'O, brother, where art thou?' The Labour Party leadership election of 2010. British Politics 6(3): 286-316.

Dorey, P. and Denham, A. (2016) 'The longest suicide vote in history': The Labour Party leadership election of 2015. British Politics 11(3): 259-282.

Drucker, H.M. (1976) Leadership selection in the Labour Party. Parliamentary Affairs 29(4): 378-395.

Drucker, H.M. (1981) Changes in the Labour Party leadership. Parliamentary Affairs 34(4): 369-391.

Drucker, H.M. (1984) Intra-Party democracy in action: The election of leader and deputy leader of the Labour Party in 1983. Parliamentary Affairs 37(3): 283-300.

Dunford, D. and Kirk, A. (2016) Tory leadership contest. How Theresa's May’s victory over Andrea Leadsom and unfolded. The Telegraph, $11^{\text {th }}$ July, available at http://www.telegraph.co.uk/news/0/who-are-the-favourites-to-become-prime-minister-afterthe-brexit/

Ennser-Jedenastik, L. and Muller, W.C. (2014) The selection of party leaders in Austria: Channelling ambition effectively. In: J.-B. Pilet and W.P. Cross (eds.) The Selection of Political Party Leaders in Contemporary Parliamentary Democracies: A Comparative Study. Abingdon: Routledge: 62-76.

Ford Library. (1975a) White House Central File CO160, Box 56, George Springsteen to Brent $\begin{array}{lllll}\text { Scowcroft, } & 4 & \text { February } & \text { (Thatcher } & \text { Foundation }\end{array}$ http://www.margaretthatcher.org/document/110507). Ford Library. (1975b) White House NSC Country File Box 15, George Springsteen to Brent Scowcroft, 11 February (Thatcher Foundation Archives, 
http://www.margaretthatcher.org/document/110508).

Francis, M. (2010) The "bland leading the bland": Electing the Liberal Democrat leader, 19882007. Representation 46(1): 91-100.

Francis, M. and Denham, A. (2015) Tim Farron wins Liberal Democrat leadership election. The Conversation, $16^{\text {th }}$ July.

Gilmour, I. and Garnett, M. (1997) Whatever Happened to the Tories? The Conservative Party since 1945. London: Fourth Estate.

Hailsham, Lord. (1975) The Door Wherein I Went. London: Collins.

Heppell, T. (2008) Choosing the Tory Leader: Conservative Party Leadership Elections from Heath to Cameron. London: I.B. Tauris.

Heppell, T. (2010a) The Labour Party leadership election of 1963: Explaining the unexpected election of Harold Wilson. Contemporary British History 24(2): 151-171.

Heppell, T. (2010b) Choosing the Labour Leader: Labour Party Leadership Elections from Wilson to Brown. London: I.B. Tauris.

Heppell, T. and Crines, A. (2011) How Michael Foot won The Labour leadership. Political Quarterly 82(1): 81-94.

Heppell, T., Crines, A. and Nicholls, R. (2010) Ideological alignments within the Parliamentary Labour Party and the leadership election of 1976. British Politics 5(1): 65-91.

Heppell, T. and Hill, M. (2008) The Conservative Party Leadership Election of 1997: An Analysis of the Voting Motivations of Conservative Parliamentarians, British Politics 3(1): 63-91.

Heppell, T. and Hill, M. (2009) Transcending Thatcherism? Ideology and the Conservative Party Leadership Mandate of David Cameron, The Political Quarterly 80(3): 388-399.

Heppell, T. and Hill, M. (2010) The Voting Motivations of Conservative Parliamentarians in the Conservative Party Leadership Election of 2001, Politics 30(.1): 36-51. 
Home, Lord. (1976) The Way the Wind Blows. London: Collins.

Hurst, G. (2006) Charles Kennedy: A Tragic Flaw. London: Politico’s.

Ilonszki, G. and Varnagy. R. (2014) Stable leadership in the context of party change: The Hungarian case. In: J.-B. Pilet and W.P. Cross (eds.) The Selection of Political Party Leaders in Contemporary Parliamentary Democracies: A Comparative Study. Abingdon: Routledge, 156-170.

Ingham, R. (2015) Jeremy Thorpe. In: D. Brack, R.Ingham and T. Little (eds.) British Liberal Leaders: Leaders of the Liberal Party, SDP and Liberal Democrats since 1828. London: Biteback Publishing, 311-319.

Jenkins, R. (1991) A Life at the Centre. London: Macmillan.

Jobson, R. and Wickham-Jones, M. (2011) Reinventing the block vote? Trade unions and the 2010 Labour Party leadership election. British Politics 6(3): 317-344.

Johnston, R. (1988) The final choice: Its social, organizational, and ideological bases. In: G. Perlin (ed.), Party Democracy in Canada: The Politics of National Party Conventions. Scarborough: Prentice Hall.

Kenig, O. (2009) Democratization of party leadership selection: Do wider selectorates produce more competitive contests? Electoral Studies 28(2): 240-247.

Kerr, P. (2007) Cameron Chameleon and the current state of Britain's consensus. Parliamentary Affairs 60(1): 46-65.

Kerr, P. and Hayton, R. (2015) Whatever happened to Conservative Party modernisation? British Politics 10(2): 114-130.

Lisi, M. and Freire, A. (2014) The selection of party leaders in Portugal. In: J.-B. Pilet and W.P. Cross (eds.) The Selection of Political Party Leaders in Contemporary Parliamentary Democracies: A Comparative Study. Abingdon: Routledge, 124-140.

Macmillan, H. (1973) At the End of the Day, 1961-1963. London: Macmillan. 
Merrick, J. (2008) Meet the real leader of the Liberal Democrats. Independent on Sunday, $6^{\text {th }}$ April.

Norton, P. (1990) Choosing a leader: Margaret Thatcher and the Parliamentary Conservative Party, 1975-1990. Parliamentary Affairs 43(3): 249-259.

Pemberton, H. and Wickham-Jones, M. (2013) Brothers all: The operation of the Electoral College in the 2010 Labour leadership contest. Parliamentary Affairs 66(4): 708-731.

Pilet, J.-B. and Cross, W.P. (eds.) (2014) The Selection of Political Party Leaders in Contemporary Parliamentary Democracies: A Comparative Study. Abingdon: Routledge.

Pilet, J.-B., and Wauters, B. (2014) The selection of party leaders in Belgium. In: J.-B. Pilet and W.P. Cross (eds.) The Selection of Political Party Leaders in Contemporary Parliamentary Democracies: A Comparative Study. Abingdon: Routledge, 30-46.

Prior, J. (1986) A Balance of Power. London: Hamish Hamilton.

Punnett, R.M. (1992) Selecting the Party Leader: Britain in Comparative Perspective. Hemel Hempstead: Harvester Wheatsheaf.

Quinn, T. (2010) Membership ballots in party leadership elections in Britain. Representation 46(1): 101-117.

Quinn, T. (2012) Electing and Ejecting Party Leaders in Britain. Basingstoke: Palgrave Macmillan.

Quinn, T. (2016) The British Labour Party's leadership election of 2015. British Journal of Politics and International Relations 18(4): 759-778.

Sandri, G., Seddone, A. and Venturino, F. (2014) The selection of party leaders in Italy, 19892012. In: J.-B. Pilet and W.P. Cross (eds.) The Selection of Political Party Leaders in Contemporary Parliamentary Democracies: A Comparative Study. Abingdon: Routledge, 93107.

Sjoblom, G. (1968) Party Strategies in a Multi-Party System. Lund: Studentlitteratur. 
Smith, H. (1999) The 1988 leadership campaign. Journal of Liberal Democrat History 24 (Autumn): 18-22.

Stark, L.P. (1996) Choosing a Leader: Party Leadership Contests in Britain from Macmillan to Blair. Basingstoke: Macmillan.

Steel, D. (1989) Against Goliath: David Steel's Story. London: Weidenfeld and Nicolson.

Thorpe, J. (1999) In My Own Time. London: Politico’s.

Wallace, W. (1983) Survival and revival. In: V. Bogdanor (ed.) Liberal Party Politics. Oxford: Clarendon Press, 43-72.

Whitelaw, W. (1989) The Whitelaw Memoirs, London: Aurum Press.

Wickham-Jones, M. (1997) Right turn: A revisionist account of the 1975 Conservative leadership election. Twentieth Century British History 8(1): 74-89.

YouGov. (2006) Survey of Liberal Democratic party members. Poll for John Stevens, 7-9 February, available at http://www.yougov.co.uk.

You Gov. (2007) Liberal Democrat leadership contest. Poll for Sky News, 3 December, available at http://www.yougov.co.uk. 